\title{
Ectothiorhodospira variabilis sp. nov., an alkaliphilic and halophilic purple sulfur bacterium from soda lakes
}

Correspondence Johannes F. Imhoff jimhoff@ifm-geomar.de

\author{
Vladimir M. Gorlenko, ${ }^{1}$ Irina A. Bryantseva, ${ }^{1}$ Sandra Rabold, ${ }^{2}$ \\ Tatjana P. Tourova, ${ }^{1}$ Dariya Rubtsova, ${ }^{1}$ Ekaterina Smirnova, ${ }^{1}$ Vera Thiel ${ }^{2}$ \\ and Johannes F. Imhoff ${ }^{2}$ \\ ${ }^{1}$ Winogradsky Institute of Microbiology, Russian Academy of Sciences, pr. 60-letiya Oktyabrya 7 k. \\ 2, 117811 Moscow, Russia \\ ${ }^{2}$ Leibnitz-Institut für Meereswissenschaften IFM-GEOMAR, Marine Mikrobiologie, Düsternbrooker \\ Weg 20, 24105 Kiel, Germany
}

The purple sulfur bacteria of the family Ectothiorhodospiraceae are widespread in brackish, saline, hypersaline environments and in soda lakes with widely different contents of total salts (Imhoff et al., 1978, 1979; Imhoff, 2001, 2006). In recent years, several novel alkaliphilic representatives of the Ectothiorhodospiraceae have been described (Bryantseva et al., 1999; Gorlenko et al., 2004). In soda lakes with elevated contents of total salts, the most frequently found species are Ectothiorhodospira haloalk-

The GenBank/EMBL/DDBJ accession numbers for the 16S rRNA, cbbL and nifH gene sequences of strain $\mathrm{WN}_{2} 2^{\top}$ are respectively AM943121, EU503123 and EU503124. Those for the 16S rRNA gene sequences of strains M16gv, KuIR, WN21R and WN21Y are respectively AM943122-AM943125.

Phylogenetic trees based on deduced amino acid sequences of $c b b L$ and $\mathrm{nifH}$ are available as supplementary material with the online version of this paper. aliphila and Halorhodospira halophila (Imhoff, 2006; Sorokin et al., 2004; Gorlenko, 2007).

We studied samples from microbial mats and biofilms of shallow-water soda lakes with various contents of total salts, located in different geographical zones: in the Transbaikalian Kulunda steppe area in south-western Siberia (Russia), in the Wadi Natrun (Egypt) and in Mongolia. During these studies, a novel, genetically distinct group of bacteria was identified as belonging to the genus Ectothiorhodospira and being most closely related to Ect. haloalkaliphila.

The basal medium used for isolation and cultivation of phototrophic purple sulfur bacteria contained (per litre distilled water) $0.5 \mathrm{~g} \mathrm{NH}_{4} \mathrm{Cl}, 0.5 \mathrm{~g} \mathrm{KH}_{2} \mathrm{PO}_{4}, 0.2 \mathrm{~g} \mathrm{MgCl}_{2}$, $50 \mathrm{~g} \mathrm{NaCl}, 15 \mathrm{~g} \mathrm{NaHCO}_{3}, 5 \mathrm{~g} \mathrm{Na}_{2} \mathrm{CO}_{3}, 0.1$ g yeast extract, $0.5 \mathrm{~g}$ sodium acetate, $0.5 \mathrm{~g} \quad \mathrm{Na}_{2} \mathrm{~S} .9 \mathrm{H}_{2} \mathrm{O}, \quad 0.5 \mathrm{~g}$ $\mathrm{Na}_{2} \mathrm{~S}_{2} \mathrm{O}_{3} \cdot 5 \mathrm{H}_{2} \mathrm{O}, 20 \mu \mathrm{g}$ vitamin $\mathrm{B}_{12}$ and $1 \mathrm{ml}$ trace element solution (Pfennig \& Lippert, 1966). For photoautotrophic 
growth conditions, yeast extract and acetate were omitted. The $\mathrm{pH}$ was adjusted to 9.0-9.5. Samples collected from the littoral zone of alkaline soda lakes were kept in sterile $50 \mathrm{ml}$ Falcon tubes at $6{ }^{\circ} \mathrm{C}$ and $1 \mathrm{ml}$ samples from each of the lakes were inoculated in $15 \mathrm{ml}$ tubes containing agar $(0.7 \%)$ medium. Pure cultures were obtained by repeated deep-agar dilution series of separately developed colonies. The cultures were grown phototrophically in screw-capped bottles at $30-35{ }^{\circ} \mathrm{C}$ and a light intensity of $2000 \mathrm{~lx}$. Oxygen relations were judged from the growth pattern in an oxygen gradient generated in deep-agar tubes equally inoculated with the test organism. For determination of organic substrate utilization, a nutrient mineral medium was used with sulfide $\left(0.5 \mathrm{~g} \mathrm{l}^{-1}\right)$, thiosulfate $\left(0.5 \mathrm{~g} \mathrm{l}^{-1}\right)$ and yeast extract $\left(0.05 \mathrm{~g} \mathrm{l}^{-1}\right)$ and supplemented with the different substrates. The organic substrates to be tested were added at concentrations of $0.5 \mathrm{~g} \mathrm{l}^{-1}$. To elucidate the utilization of electron donors and carbon and sulfur sources, as well as the reaction to different $\mathrm{pH}$ and $\mathrm{NaCl}$ concentrations, the basal medium supplemented with yeast extract and acetate was used and the parameters under study were varied accordingly. The growth yield was measured on the basis of $\mathrm{OD}_{650}$ measured with a KFK-3 photometer [Optico-Mechanikal Plant (ZOMP)] in the stationary growth phase, when the culture did not contain elemental sulfur. Utilization of sulfur compounds and their oxidation products were studied in batch cultures of the bacteria. Concentrations of thiosulfate, sulfite and $\mathrm{H}_{2} \mathrm{~S}+\mathrm{HS}^{-}$were determined by iodometric titration (Reznikov et al., 1970). Sulfate was determined turbidimetrically (Dodgson, 1961).

Cell morphology was studied by light and electron microscopy. Intact cells were stained with $2 \%$ uranyl acetate. Ultrathin sections were prepared as described previously (Ryter et al., 1958; Bryantseva et al., 1999).

Cells were suspended in $50 \%$ glycerol for measurement of absorption spectra of living cells, which were recorded with an SPh-56 spectrophotometer (LOMO). In addition, pigments were extracted with acetone/methanol $(7: 2$, $\mathrm{v} / \mathrm{v}$ ), and absorption spectra of these extracts were also recorded. Carotenoids were extracted from bacterial chromatophore suspensions with acetone/methanol $(7: 2)$. The pigments were thereafter brought into petroleum, redissolved in methylene chloride and separated by HPLC as described by Moskalenko et al. (1995).

DNA of pure cultures was extracted using the QIAamp DNA Mini kit (Qiagen) for analysis of $16 \mathrm{~S}$ rRNA, $c b b L$ and nifH gene sequences and by the phenol method for determination of the DNA base composition and for DNA-DNA hybridization studies. The DNA base composition was determined according to Owen et al. (1969) by the thermal denaturation method, and DNA-DNA hybridization was studied by the optical reassociation method (De Ley et al., 1970).

The 16S rRNA gene was amplified using eubacterial primers $5^{\prime}$-27F (5'-AGTTTGATCCTGGCTCAG-3') and
$3^{\prime}$-1492R (5'-GGTTACCTTGTTACGACTT-3') and puReTaq Ready-To-Go PCR beads (Amersham Biosciences). $c b b L$ and $n i f H$ gene fragments were amplified using specially developed and previously tested primers (Boulygina et al., 2002; Spiridonova et al., 2004; Marusina et al., 2001). PCR products were purified from lowmelting-point agarose using the Wizard PCR Preps kit (Promega). The QIAquick PCR purification kit (Qiagen) was used to purify the PCR products. Sequence data were obtained using the Sanger method (Sanger et al., 1977) with cycle-sequencing reactions and a subsequent ethanol precipitation of the DNA including purification. Automated sequence determination was performed using an ABI PRISM 310 Genetic Analyzer (ABI Applied Biosystems). The complete sequence was assembled from several fragments by using the software SeqMan II 4.03 (DNASTAR) (Swindell \& Plasterer, 1997).

Preliminary assignment of the sequences of the novel strains was performed using the NCBI BLAST server (http:// www.ncbi.nlm.nih.gov/blast/). Nucleotide and inferred amino acid sequences were aligned with sequences from GenBank using CLUSTAL W (Thompson et al., 1994). Phylogenetic trees of deduced amino acid sequences derived from nifH and $c b b L$ nucleotide sequences were reconstructed using four different algorithms: neighbourjoining (Saitou \& Nei, 1987) in the TREECONW program package (Van de Peer \& De Wachter, 1994) and maximum-likelihood using PHYLIP 3.5c software (Felsenstein, 1993). 16S rRNA gene sequences were aligned using the FASTAlign function of the alignment editor implemented in the ARB software package (http:// www.arb-home.de) (Ludwig et al., 2004) and refined manually. For phylogenetic analysis of $16 \mathrm{~S}$ rRNA gene sequences, the online version of the PhyML software (Guindon et al., 2005) was used. Phylogenetic trees were calculated using the maximum-likelihood method (Felsenstein, 1981) with the GTR model and estimated proportion of invariable sites and the gamma distribution parameter.

Altogether, 11 strains of the novel purple sulfur bacterium were isolated from samples of thin microbial mats on the surface of sulfide-containing sediments of various soda lakes. The lakes were located in geographically remote areas in Egypt (Lake Hamra and Lake Um Risha; $30^{\circ} 30^{\prime}$ to $30^{\circ}$ $20^{\prime} \mathrm{N} 30^{\circ} 15^{\prime}$ to $30^{\circ} 25^{\prime} \mathrm{E}$ ), Mongolia (Lake Shara Burdin nur; $\left.48^{\circ} 19^{\prime} 30^{\prime \prime} \mathrm{N} 114^{\circ} 31^{\prime} 33^{\prime \prime} \mathrm{E}\right)$ and south-western Siberia (Lake Tanatar in the Kulunda steppe; $51^{\circ} 39^{\prime} 57^{\prime \prime} \mathrm{N}$ $79^{\circ} 44^{\prime} 59^{\prime \prime} \mathrm{E}$ ) (Table 1). The locations of these lakes have been described previously (Imhoff et al. 1979; Sorokin et al., 2004; Foti et al., 2007). At the time of this investigation, the content of total salts of these lakes varied from 165 to $333 \mathrm{~g}$ $1^{-1}$ and the $\mathrm{pH}$ ranged from 9.4 to 10.3. All new isolates had similar physiological properties and absorption spectra. For comparison, Ect. haloalkaliphila BN $9903^{\mathrm{T}}$, Ect. shaposhnikovii DSM $243^{\mathrm{T}}$ and Hlr. halophila DSM $244^{\mathrm{T}}$ were used. 
Table 1. Total salt content and $\mathrm{pH}$ of soda lakes from which strains of the novel bacterium were isolated

\begin{tabular}{|c|c|c|c|}
\hline Strain & Lake & Total salts $\left(\mathrm{g} \mathrm{l}^{-1}\right)$ & pH \\
\hline \multicolumn{4}{|c|}{ Egypt, Wadi Natrun } \\
\hline WN1E & Hamra & 210 & 9.6 \\
\hline $\mathrm{WN} 21 \mathrm{Y}$ & Hamra & 210 & 9.6 \\
\hline WN21R & Hamra & 210 & 9.6 \\
\hline $\mathrm{WN} 22^{\mathrm{T}}$ & Um-Risha & 320 & 9.35 \\
\hline WN2R & Um-Risha & 320 & 9.35 \\
\hline WN3gv & Fazda & 250 & 9.7 \\
\hline \multicolumn{4}{|c|}{ North-eastern Mongolia } \\
\hline $\mathrm{M}-16 \mathrm{aE}$ & Shara Burdin nur & 210 & 9.9 \\
\hline $\mathrm{M}-16 \mathrm{gv}$ & Shara Burdin nur & 210 & 9.9 \\
\hline $\mathrm{M}-16 \mathrm{E}$ & Shara Burdin nur & 210 & 9.9 \\
\hline $\mathrm{M}-24 \mathrm{E}$ & Shara Burdin nur & 165 & $9.8-10.3$ \\
\hline \multicolumn{4}{|c|}{ South-western Siberia, Kulunda steppe } \\
\hline KulR & Tanatar I & 333 & 10 \\
\hline
\end{tabular}

The cell morphology of all the new isolates was similar. Cells were oval- to rod-shaped or formed weakly twisted spirals (Fig. 1a, b). The cells varied from 0.8 to $1.2 \mu \mathrm{m}$ in width and 1.2 to $1.5 \mu \mathrm{m}$ in length. Cells were motile by means of flagella and multiplied by binary fission. In the late phase of growth, cells of most of the strains formed gas
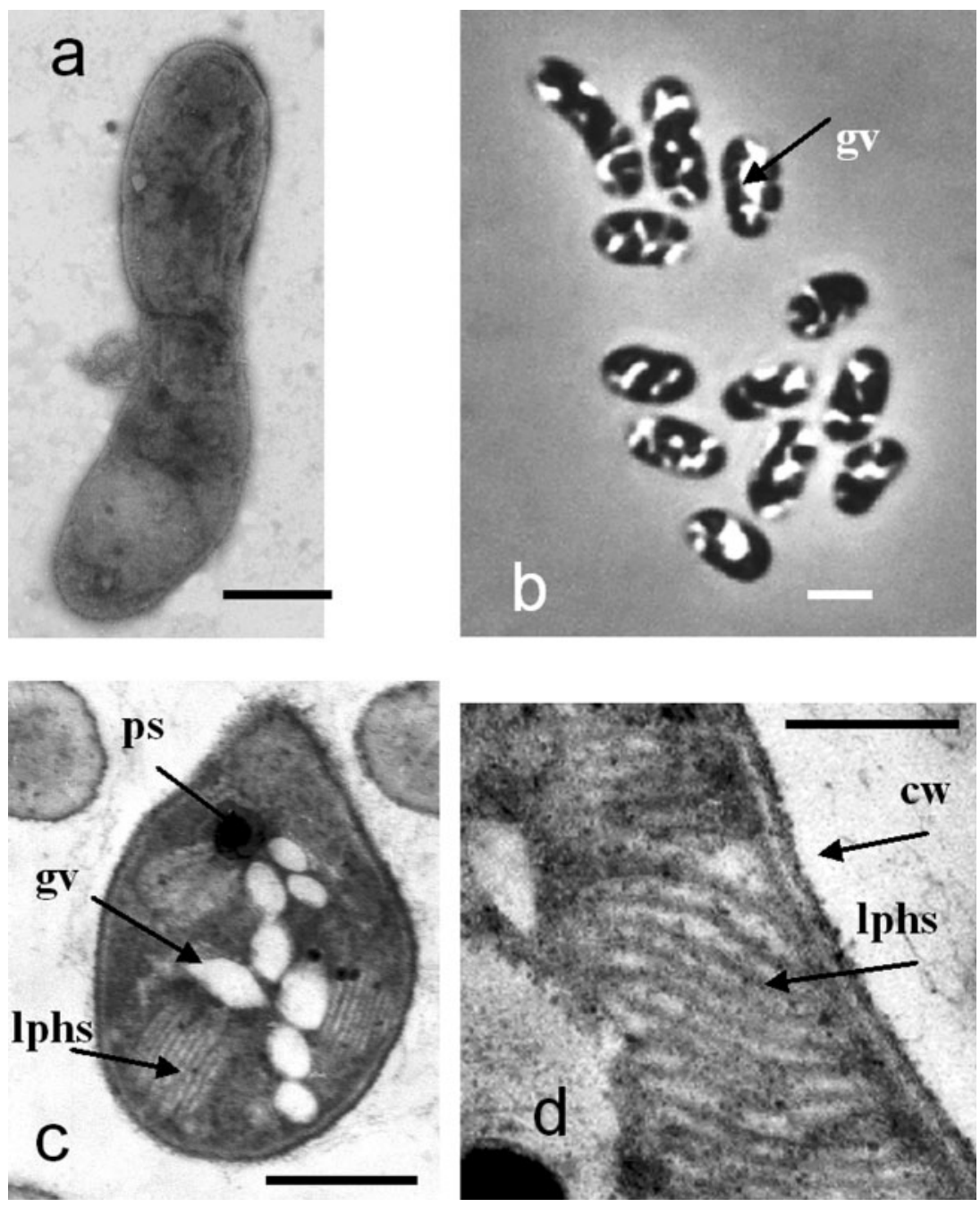

Fig. 1. Micrographs of strain $\mathrm{WN} 22^{\top}$ showing the morphology [(a) whole cell, electron microscopy; (b) phase-contrast microscopy] and fine structure [(c, d) electron microscopy]. Bars, $1 \mu \mathrm{m}$ (a, c), $2 \mu \mathrm{m}$ (b) and $0.5 \mu \mathrm{m}$ (d). ps, Polyphosphate-like particles; Iphs, lamellar photosynthetic membranes; gv, gas vesicles; $\mathrm{cw}$, cell wall. 
vesicles and floated to the top of the bottles. Gas vesicles were more numerous in medium containing yeast extract and acetate compared with photoautotrophic growth conditions. In cells of strain $\mathrm{WN} 22^{\mathrm{T}}$ and most other investigated strains of the novel species, gas vesicles were shaped like cylinders with pointed ends (Fig. 1c). The only species of the Ectothiorhodospiraceae so far known to form gas vesicles is Ectothiorhodospira vacuolata (Table 2; Imhoff et al., 1981). Ultrathin sections of cells of strain WN22 ${ }^{\mathrm{T}}$ showed a Gram-negative type of cell wall (Fig. 1d). The internal photosynthetic membranes were lamellae, located in ordered stacks, as in the majority of known species of the Ectothiorhodospiraceae. Dense oval inclusions, characteristic of polyphosphates, were seen regularly in the cells (Fig. 1c).

The pigments of all investigated isolates of the novel species were bacteriochlorophyll $a$ and carotenoids. Cell suspensions were purple red or deep red in colour if grown under anaerobic conditions in the light. The absorption maxima at $370-373,586-590,797-799,833$ (for strain $\mathrm{WN} 22^{\mathrm{T}}$ ) or $845-851$ (for other strains) and $889 \mathrm{~nm}$ characterized the presence of bacteriochlorophyll $a$. The maximum at 508$512 \mathrm{~nm}$ and shoulders at $483-489$ and $546-552 \mathrm{~nm}$ are indicative of the presence of carotenoids of the normal spirilloxanthin series. A more detailed analysis of the carotenoids of strain $\mathrm{WN} 22^{\mathrm{T}}$ confirmed spirilloxanthin as the major component ( $44.7 \%$ of total carotenoids), with anhydrorhodovibrin (23.8\%), demethylspirilloxanthin (21.4\%), lycopene $(6.8 \%)$ and dehydrorhodopin $(3.7 \%)$ as additional components.

The novel bacterium is strictly anaerobic. Good growth was observed photoautotrophically with sulfide, thiosulfate or elemental sulfur as the electron donor and carbonate as carbon source. While assimilatory sulfate reduction was absent, sulfide, thiosulfate or sulfite could be used as a source of cellular sulfur. In the presence of sulfide and carbonate, acetate, Casamino acids, yeast extract, lactate, malate, propionate, pyruvate, succinate and fumarate were used as organic substrates. Arginine, aspartate, butyrate, benzoate, valerate, glycerol, glucose, glutamate, caprylate, caproate, malonate, mannitol, methanol, propanol, sorbitol, tartrate, formate, fructose, citrate and ethanol are not used by any of investigated isolates. The novel bacterium grew well under photoheterotrophic conditions with $1 \mathrm{~g}$ acetate $1^{-1}$ in the presence of $0.1 \mathrm{~g}$ sulfide $\mathrm{l}^{-1}$ as a source of sulfur. Vitamins were not required, but yeast extract $\left(0.05 \mathrm{~g}^{-1}\right)$ stimulated growth rates appreciably without influencing the final yield in the stationary growth phase.

\section{Table 2. Major characteristic and distinguishing properties of Ectothiorhodospira species}

Data for reference species were taken from Imhoff et al. (1981), Imhoff \& Süling (1996) and Imhoff (2001, 2006). +, Characteristic positive or substrate utilized by most strains; -, characteristic negative or substrate not utilized by most strains; $(+)$, weak reaction; ND, not determined. All species are motile. Sulfide and sulfur are utilized by all species. Acetate, malate, fumarate, succinate and pyruvate are used by all species.

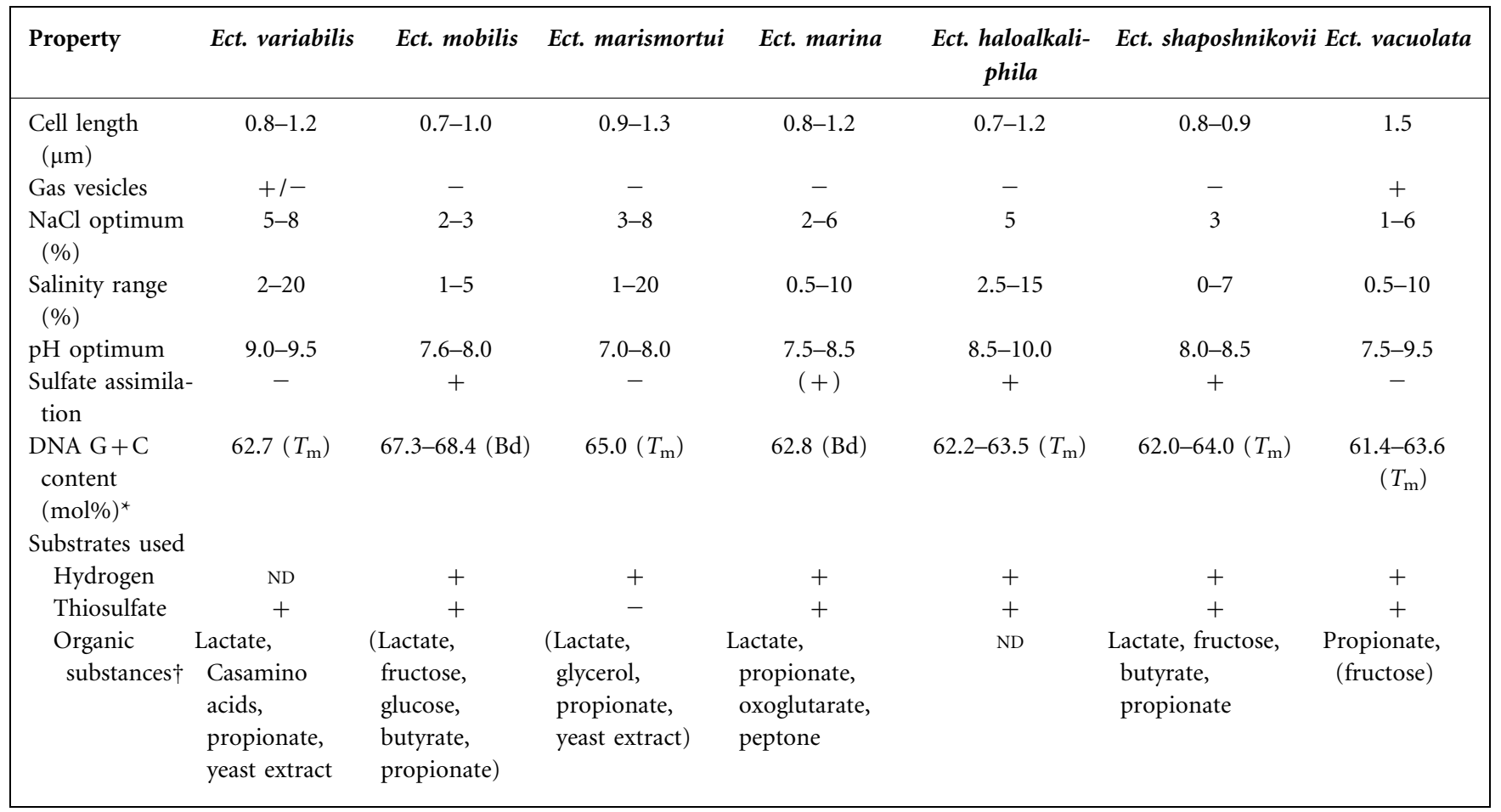

${ }^{*}$ Values are for type strains. Bd, Buoyant density; $T_{\mathrm{m}}$, thermal denaturation.

$\dagger$ Substrates in parentheses are utilized by some strains. 


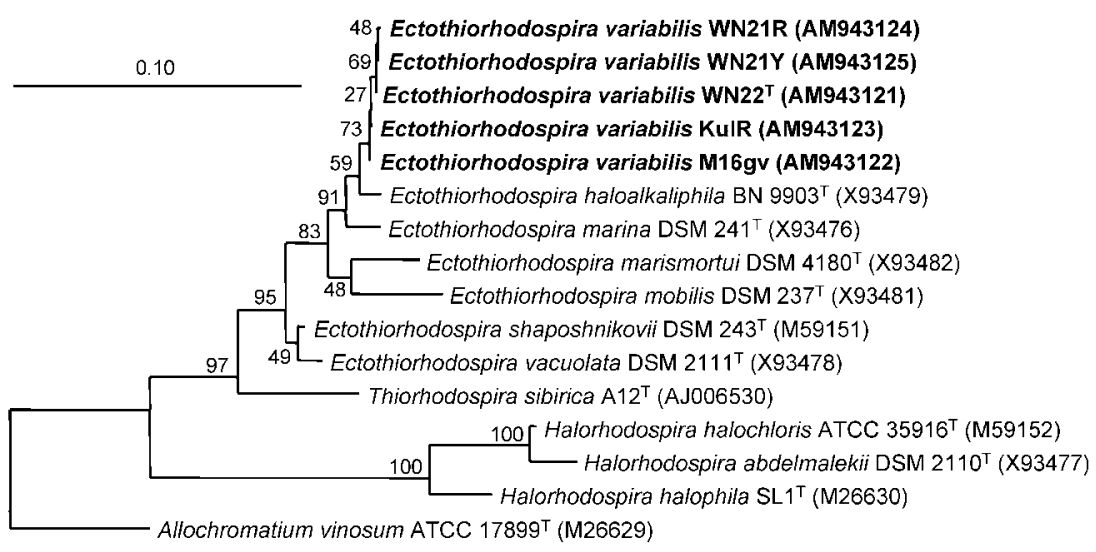

Fig. 2. Phylogenetic tree illustrating the relationships of strain $\mathrm{WN}_{2} 2^{\top}$ and related purple sulfur bacteria based on 16S rRNA gene sequence comparison. The tree was generated by the maximum-likelihood method. Bar, 10 nucleotide substitutions per 100 positions. Numbers indicate percentages of bootstrap sampling, derived from 100 replications.
Under both photoautotrophic and photolithoheterotrophic conditions, sulfide and thiosulfate are transformed to elemental sulfur, which is deposited outside the cells, and further oxidized to sulfate after depletion of sulfide from the culture medium (data not shown). The novel bacterium is mesophilic and haloalkaliphilic. The salinity range indicates clearly that it is moderately halophilic. Growth optima are at 30-35 ${ }^{\circ} \mathrm{C}$ (range $20-45^{\circ} \mathrm{C}$ ), $\mathrm{pH} 9.0-9.5$ (range $\mathrm{pH} 7.5-10.0$ ) and $5-8 \% \mathrm{NaCl}$ (range 2-20\% NaCl). The novel bacterium does not grow in the absence of $\mathrm{NaCl}$.

The novel species is distinct from Ect. haloalkaliphila, the closest relative, in the lack of sulfate assimilation, the presence of only weak chemotrophic growth in the darkness under microaerobic conditions, the presence of gas vesicles in the majority of the strains, growth over a wider range of salt concentrations $(2-20 \% \mathrm{NaCl})$, the colour of the cell suspension, reflecting different proportions of carotenoids, and its preference for growth in the presence of yeast extract and acetate but at low concentrations of sulfide (approx. $1 \mathrm{mM}$ ).
Analysis of the 16S rRNA gene sequence was used to reveal the phylogenetic position of five of the new isolates (Fig. 2). They are clearly assigned to the genus Ectothiorhodospira and are most similar to Ect. haloalkaliphila. According to BLAST analysis, the highest sequence similarities were found to Ect. haloalkaliphila $\mathrm{BN} 9903^{\mathrm{T}}$, with values of approx. $98 \%$. This is in agreement with the outline by Stackebrandt \& Ebers (2006), that the 16S rRNA gene sequences are sufficiently different to recognize the new isolates as members of an independent species. The DNA base composition of purified DNA of strain $\mathrm{WN} 22^{\mathrm{T}}$ is $62.7 \mathrm{~mol} \% \mathrm{G}+\mathrm{C}$ (Table 3). DNA-DNA hybridization showed that the level of DNA relatedness between the new isolates was $68-98 \%$ (above $85 \%$ in most cases) and that between these new isolates and Ect. haloalkaliphila $\mathrm{BN}$ $9903^{\mathrm{T}}$ was only $30-42 \%$ (Table 3 ). These data indicate that all of these isolates can be regarded as strains of a single novel species.

In addition, we undertook a phylogenetic analysis of two other genes coding for enzymes important for the life of

Table 3. DNA-DNA hybridization between investigated strains

\begin{tabular}{|c|c|c|c|c|c|c|c|c|c|c|}
\hline \multirow[t]{2}{*}{ Strain } & \multirow[t]{2}{*}{$\mathrm{G}+\mathrm{C}$ content $(\mathrm{mol} \%)$} & \multicolumn{9}{|c|}{ DNA-DNA relatedness with $(\%)$ : } \\
\hline & & 1 & 2 & 3 & 4 & 5 & 6 & 7 & 8 & 9 \\
\hline Hlr. halophila DSM $244^{\mathrm{T}}$ & 66.4 & 11 & & & & & & & & \\
\hline Ect. shaposhnikovii DSM $243^{\mathrm{T}}$ & 61.5 & 25 & & & & & & & & \\
\hline 1. Ect. haloalkaliphila $\mathrm{BN} 9903^{\mathrm{T}}$ & 62.5 & 100 & & & & & & & & \\
\hline 2. $\mathrm{WN} 1 \mathrm{E}$ & 63.3 & 30 & 100 & & & & & & & \\
\hline 3. WN21Y & 62.3 & - & - & 100 & & & & & & \\
\hline 4. $\mathrm{WN} 21 \mathrm{R}$ & 62.5 & 33 & - & 98 & 100 & & & & & \\
\hline 5. $\mathrm{WN} 22^{\mathrm{T}}$ & 62.7 & 33 & - & - & 91 & 100 & & & & \\
\hline 6. WN2R & - & 34 & - & 89 & 85 & - & 100 & & & \\
\hline 7. M16aE & 62.6 & 42 & 95 & - & 87 & - & - & 100 & & \\
\hline 8. M24E & 62.5 & - & 88 & - & - & - & - & - & 100 & \\
\hline 9. M16gv & 62.4 & - & 91 & - & - & - & - & 89 & 78 & 100 \\
\hline KulR & 62.5 & 41 & 68 & - & - & - & - & 92 & - & - \\
\hline
\end{tabular}

-, Not determined. 
phototrophic bacteria. The gene $c b b L$ encodes the enzyme ribulose-1,5-bisphosphate carboxylase/oxygenase (RuBisCo), required for autotrophic $\mathrm{CO}_{2}$ fixation, and nifH encodes the enzyme nitrogenase, which enables the fixation of dinitrogen. Similar to other members of the Ectothiorhodospiraceae, we found only a 'green-like' $c b b L$ sequence (a 750 bp fragment) in strain $\mathrm{WN} 22^{\mathrm{T}}$. After conceptual translation of 'green-like' $c b b L$ gene fragments, we compared 231 positions with reference $c b b L$ sequences of phototrophic members of the Ectothiorhodospiraceae (Supplementary Fig. S1, available in IJSEM Online). In this tree, the members of the genus Ectothiorhodospira formed a single cluster, similar to the $16 \mathrm{~S}$ rRNA gene tree, and again strain $\mathrm{WN} 22^{\mathrm{T}}$ was closely related to Ect. haloalkaliphila BN $9903^{\mathrm{T}}(98.7 \%$ amino acid sequence identity). Its similarity to other Ectothiorhodospira species was significantly lower $(88.3-85.8 \%)$. Thus, the results of $c b b L$ sequence analysis support the results from 16S rRNA gene sequence analysis and DNA-DNA hybridization, indicating the divergence of the new isolates (represented by strain $\mathrm{WN} 22^{\mathrm{T}}$ ) from other members of the Ectothiorhodospiraceae at the species level. The presence of nifH genes has been demonstrated for the species of Ectothiorhodospira, Halorhodospira and Thiorhodospira (Tourova et al., 2007). The sequence of strain $\mathrm{WN} 22^{\mathrm{T}}$ again showed the highest similarity to that of Ect. haloalkaliphila BN $9903^{\mathrm{T}}$ (almost $100.0 \%$ ) and just $94.0-94.6 \%$ to other Ectothiorhodospira species (Supplementary Fig. S2).

On the basis of sequence similarity of the $16 \mathrm{~S}$ rRNA gene, supported by sequence similarity of the $c b b L$ and nifH genes, as well as results of DNA-DNA hybridization and a number of phenotypic properties, we propose that the newly isolated strains should be placed into a novel species, for which the name Ectothiorhodospira variabilis sp. nov. is proposed.

\section{Description of Ectothiorhodospira variabilis sp. nov.}

Ectothiorhodospira variabilis (va.ri.a'bi.lis. L. fem. adj. variabilis varied, changeable).

Cells are ovals, rods or weakly twisted spirals, 0.8$1.2 \times 1.2-1.5 \mu \mathrm{m}$. Young cells are motile by means of polar flagella. Most strains contain gas vesicles, in particular under photoheterotrophic growth conditions. Internal photosynthetic membranes are lamellar stacks. Colour of cell suspensions with gas vesicles is purple red, in their absence deep red. Absorption spectra have maxima at 370 373, (483-489), 508-512, (546-552), 586-590, 797-799, 833 (or 845-851) and $889 \mathrm{~nm}$. Photosynthetic pigments are bacteriochlorophyll $a$ and carotenoids of the spirilloxanthin series. In the type strain, the composition is $44.7 \%$ spirilloxanthin, $\quad 23.8 \%$ anhydrorhodovibrin, $\quad 21.4 \%$ demethylspirilloxanthin, $6.8 \%$ lycopene and $3.7 \%$ dehydrorhodopin. Photoautotrophic growth occurs anaerobically in the light with sulfide, thiosulfate or elemental sulfur as electron donor and bicarbonate. Best growth occurs under photoheterotrophic conditions, under which small amounts of reduced sulfur compounds are required for biosynthesis. Chemoautotrophic and chemoheterotrophic growth is possible under microoxic conditions in presence of sulfide. Assimilatory sulfate reduction is not possible. Organic carbon sources and electron donors used are acetate, Casamino acids, yeast extract, lactate, malate, propionate, pyruvate, succinate and fumarate, yeast extract and Casamino acids. Butyrate, benzoate, valerate, glycerol, glucose, glutamate, caprylate, caproate, malonate, mannitol, methanol, propanol, sorbitol, tartrate, formate, fructose, citrate, ethanol, arginine and aspartate are not assimilated. Nitrogen sources are ammonia and some amino acids. Growth factors are not required, but yeast extract stimulates growth. Alkaliphilic and moderately halophilic. $\mathrm{NaCl}$ is required for growth. Optimum growth is at $\mathrm{pH}$ 9.0-9.5 (range $\mathrm{pH} 7.5-10.0$ ), $5-8 \% \mathrm{NaCl}$ (range $2-20 \%$ ) and $30-35{ }^{\circ} \mathrm{C}$ (range $20-45{ }^{\circ} \mathrm{C}$ ). The $\mathrm{G}+\mathrm{C}$ content of the DNA is $62.3-63.3 \mathrm{~mol} \%\left(T_{\mathrm{m}}\right)$.

The type strain is strain $\mathrm{WN} 22^{\mathrm{T}}\left(=\mathrm{VKM} \mathrm{B}-2479^{\mathrm{T}}=\mathrm{DSM}\right.$ $21381^{\mathrm{T}}$ ), isolated from the Um-Risha soda lake at Wadi Natrun in Egypt.

\section{Acknowledgements}

This work was supported by grants no. 07-04-10149 and 08-04-0004 from the Russian Foundation for Basic Research N, the Program RAS 'Molecular and Cell Biology' and the Program RAS 'Origin and evolution of a life on the Earth' and the Russian Science Support Foundation. The authors thank A. M. Lysenko for determination of the DNA G + C content and for the DNA-DNA hybridization, N. A. Kostrikina for preparation of the ultrathin sections, Z. K. Mahneva and A. A. Moskalenko for carotenoid analysis, D. Yu. Sorokin for supplying environmental samples and E. V. Spiridonova and N. V. Slobodova for sequence analysis of $c b b L$ and nifH genes.

\section{References}

Boulygina, E. S., Kuznetsov, B. B., Marusina, A. I., Tourova, T. P., Kravchenko, I. K., Bykova, S. A., Kolganova, T. V. \& Galchenko, V. F. (2002). A study of nucleotide sequences of nifH genes of some methanotrophic bacteria. Microbiology (English translation of Mikrobiologiia) 71, 425-432.

Bryantseva, I., Gorlenko, V. M., Kompantseva, E. I., Imhoff, J. F., Süling, J. \& Mityushina, L. (1999). Thiorhodospira sibirica gen. nov., sp. nov., a new alkaliphilic purple sulfur bacterium from a Siberian soda lake. Int J Syst Bacteriol 49, 697-703.

De Ley, J., Cattoir, H. \& Reynaerts, A. (1970). The quantitative measurement of DNA-DNA hybridization from renaturation rates. Eur J Biochem 12, 133-142.

Dodgson, K. S. (1961). Determination of inorganic sulphate in studies on the enzymatic and nonenzymatic hydrolysis of carbohydrate and other sulphate esters. Biochem J 78, 312-329.

Felsenstein, J. (1981). Evolutionary trees from DNA-sequences - a maximum-likelihood approach. J Mol Evol 17, 368-376.

Felsenstein, J. (1993). PHYLIP (phylogeny inference package), version 3.53c. Distributed by the author. Department of Genome Sciences, University of Washington, Seattle, USA.

Foti, M., Sorokin, D. Y., Lomans, B., Mussman, M., Zacharova, E. E., Pimenov, N. V., Kuenen, J. G. \& Muyzer, G. (2007). Diversity, activity, and abundance of sulfate-reducing bacteria in saline and hypersaline soda lakes. Appl Environ Microbiol 73, 2093-2100. 
Gorlenko, V. M. (2007). Anoxygenic phototrophic bacteria of soda lake. In Proceedings of Winogradsky Institute of Microbiology, vol. XIV, Alkaliphilic Microbial Communities, pp. 225-257. Edited by V. F. Gal'chenko. Moscow: Nauka (in Russian).

Gorlenko, V. M., Bryantseva, I. A., Panteleeva, E. E., Tourova, T. P., Kolganova, T. V., Makhneva, Z. K. \& Moskalenko, A. A. (2004). Ectothiorhodosinus mongolicus gen. nov., sp. nov., a new purple bacterium from a soda lake in Mongolia. Microbiology (English translation of Mikrobiologiia) 73, 66-73.

Guindon, S., Lethiec, F., Duroux, P. \& Gascuel, O. (2005). PHYML Online - a web server for fast maximum likelihood-based phylogenetic inference. Nucleic Acids Res 33, W557-W559.

Imhoff, J. F. (2001). The anoxygenic phototrophic purple bacteria. In Bergey's Manual of Systematic Bacteriology, 2nd edn, vol. 1, pp. 621627. Edited by D. R. Boone, R. W. Castenholz \& G. M. Garrity. New York: Springer.

Imhoff, J. F. (2006). The family Ectothiorhodospiraceae. In The Prokaryotes: a Handbook on the Biology of Bacteria, 3rd edn, vol. 6, pp. 874-886. Edited by M. Dworkin, S. Falkow, E. Rosenberg, K. H. Schleifer \& E. Stackebrandt. New York: Springer.

Imhoff, J. F. \& Süling, J. (1996). The phylogenetic relationship among Ectothiorhodospiraceae. A reevaluation of their taxonomy on the basis of rDNA analyses. Arch Microbiol 165, 106-113.

Imhoff, J. F., Hashwa, F. \& Trüper, H. G. (1978). Isolation of extremely halophilic phototrophic bacteria from the alkaline Wadi Natrun, Egypt. Arch Hydrobiol 84, 381-388.

Imhoff, J. F., Sahl, H. G., Soliman, G. S. H. \& Trüper, H. G. (1979). The Wadi Natrun: chemical composition and microbial mass development in alkaline brines of eutrophic desert lakes. Geomicrobiol J 1, 219-234.

Imhoff, J. F., Tindall, B. J., Grant, W. D. \& Trüper, H. G. (1981). Ectothiorhodospira vacuolata sp. nov., a new phototrophic bacterium from soda lakes. Arch Microbiol 130, 238-242.

Ludwig, W., Strunk, O., Westram, R., Richter, L., Meier, H., Yadhukumar, Buchner, A., Lai, T., Steppi, S. \& other authors (2004). ARB: a software environment for sequence data. Nucleic Acids Res 32, 1363-1371.

Marusina, A. I., Boulygina, E. S., Kuznetsov, B. B., Tourova, T. P., Kravchenko, I. K. \& Gal'chenko, V. F. (2001). A system of oligonucleotide primers for the amplification of nifH genes of different taxonomic groups of prokaryotes. Microbiology (English translation of Mikrobiologiia) 70, 73-78.

Moskalenko, A. A., Toropygina, O. A. \& Kuznetsova, N. Yu. (1995). The isolation of the B812 subcomplex of the B880 core complex and the B800-850 complex from membranes of Chromatium minutissi- mum with extracted carotenoids: structural role of carotenoids. $J$ Photochem Photobiol B Biol 27, 199-207.

Owen, R. J., Hill, L. R. \& Lapage, S. P. (1969). Determination of DNA base composition from melting profiles in dilute buffers. Biopolymers 7, 503-516.

Pfennig, N. \& Lippert, K. D. (1966). Über das Vitamin $B_{12}$-Bedürfnis phototropher Schwefelbakterien. Arch Mikrobiol 55, 245-256 (in German).

Reznikov, A. A., Mulikovskaya, E. P. \& Sokolov, I. Yu. (1970). In Methods for Natural Water Analysis, p. 118. Moscow: Nedra (in Russian).

Ryter, A., Kellenberger, E., Birchandersen, A. \& Maaloe, O. (1958). Etude au microscope electronique des plasmes contenant de l'acide deoxyribonucleique. 1. Les nucleoides des bacteries en croissance active. $Z$ Naturforsch B 13B, 597-605 (in French).

Saitou, N. \& Nei, M. (1987). The neighbor-joining method: a new method for reconstructing phylogenetic trees. Mol Biol Evol 4, 406-425.

Sanger, F., Nicklen, S. \& Coulson, A. R. (1977). DNA sequencing with chain-terminating inhibitors. Proc Natl Acad Sci U S A 74, 5463-5467.

Sorokin, D. Yu., Gorlenko, V. M., Namsaraev, B. B., Namsaraevm, Z. B., Lysenko, A. M., Eshinimaev, B. Ts., Khmelenina, V. N., Trotsenko, Yu. A. \& Kuenen, J. G. (2004). Prokaryotic communities of the north-eastern Mongolian soda lakes. Hydrobiologia 522, 235248.

Spiridonova, E. M., Berg, I. A., Kolganova, T. V., Ivanovskii, R. N., Kuznetsov, B. B. \& Tourova, T. P. (2004). An oligonucleotide primer system for amplification of the ribulose-1,5-bisphosphate carboxylase/oxygenase genes of bacteria of various taxonomic groups. Mikrobiologiia 73, 377-387 (in Russian).

Stackebrandt, E. \& Ebers, J. (2006). Taxonomic parameters revisited: tarnished gold standards. Microbiol Today 33, 152-155.

Swindell, S. R. \& Plasterer, T. N. (1997). SEQMAN. Contig assembly. Methods Mol Biol 70, 75-89.

Thompson, J. D., Higgins, D. G. \& Gibson, T. J. (1994). CLUSTAL W: improving the sensitivity of progressive multiple sequence alignment through sequence weighting, position-specific gap penalties and weight matrix choice. Nucleic Acids Res 22, 4673-4680.

Tourova, T. P., Spiridonova, E. M., Berg, I. A., Slobodova, N. V., Boulygina, E. S. \& Sorokin, D. Yu. (2007). Phylogeny and evolution of the family Ectothiorhodospiraceae based on comparison of $16 \mathrm{~S}$ rRNA, $c b b L$ and nifH genes. Int J Syst Evol Microbiol 57, 2387-2398.

Van de Peer, Y. \& De Wachter, R. (1994). TREECON for Windows: a software package for the construction and drawing of evolutionary trees for the Microsoft Windows environment. Comput Appl Biosci 10, 569-570. 